\title{
LANGUAGE LEARNING BELIEFS OF HIGH SCHOOL STUDENTS IN BANGKA BELITUNG
}

\author{
Ihda Husnayaini \\ ihdahusnayaini@iainsasbabel.ac.id
}

\begin{abstract}
Learning a foreign language is generally one of the most challenging subjects in high school. This study discussed the beliefs of foreign language learning of high school students in Bangka Belitung, Indonesia, who planned on learning Arabic and Japanese, especially the prevalence of beliefs among different classes of learners (Arabic, Japanese and mix class) and between female and male students. The result of this study suggested that there were differences of the responses to the inventory among classes and gender but they were not significant. The students responded five aspects concerning the beliefs and they had the highest scores in Motivations and Expectations, especially the mix language class. Furthermore, female students had more positive opinion about foreign language learning, which matched some previous studies revealing that female learners were better than males in language learning.
\end{abstract}

Keywords: beliefs, foreign language learning, high school students

\section{A. Introduction}

Language learning has always been identical with second language acquisition since the language after the first one or mother tongue should be taught (Ellis, 1997). It is the teacher's job to find out how the successful learners have been doing it and what they have been doing. It is also important to identify what factors that account for why learners acquire or achieve in the way they do.

Although some experts presented a contrast between learning and acquisition; by arguing that one is conducted in a classroom and the other is obtained naturally, both actually cannot be separated, or in other words, learning should be done in any way possible. Sometimes learning is said to be gained consciously, while acquisition is acquired unconsciously. Rather they should be combined since they are required in language learning and the attempt to distinguish them is vague and unacceptable (Oxford, 1990). 
Language acquisition is also better well known as second language acquisition. This term is not necessarily referred to the language one learns after their mother tongue or first language (L1). It is related to any language they learn; be it the third or fourth or even what is also called a foreign language, inside or outside a classroom (Ellis, 2003). According to Brown (2002), Second Language Acquisition is a division of general human learning, involves cognitive variations, is closely related to one's personality type, is interwoven with second culture learning, and involves interference, the creation of new linguistics systems, and the learning of discourse and communicative functions of language.

Learning a second or foreign language has nowadays become a necessity for those who are going abroad for a higher education or for a career requirement since the growth of the so called globalization where people from different countries and communities have had to communicate each other. In a classroom setting, a teacher can find out how learners acquire an L2 by collecting samples of learner language the language that learners produce when they are called on to use an L2 in speech and writing - and analyze them carefully (Ellis, 2003). The samples can be in the form of a language test formally or informally and conducted at different times so the teacher can see how the learner language develops or changes overtime.

Language learning has always been a part of gender study since there are differences in language use between male and female learners, spoken and written. Socio-cultural aspect plays a very important role in such a distinction based on gender. In this study, the writer would like to find out whether there is a difference between male and female learners in language learning beliefs. Learning a language for adult learners, especially a foreign language usually involves preconceptions. Preconception or preconceived idea or notion is an idea or opinion that someone has before learning about or experiencing something directly (Merriam-Webster, 2018).

Indonesian people nowadays, in general, especially the youngsters, have become more familiar to English as-supposedly-their second language, thanks to the internet and social media that they regularly use on their smartphones. The writer would say 'second language' since they learn the used-to-be foreign language by mostly from the 
internet, especially social media and become quite fluent in communication using the language. However, in general, English is still considered a difficult language to learn by many Indonesian learners, compared to Malaysia, for it is a second language to Malaysian people in general, while in Indonesia, it is a foreign language.

However, in general, learning a foreign language is not an easy thing to do by most Indonesian people because Indonesia is not a multicultural and multiethnic country like the USA or Australia, for instance, where everybody can meet people from different countries with different cultures and surely languages. Indonesia, though consists of multi ethnics and various kinds of cultures, the majority are natives with different dialects (apart from the fact that some dialects are actually from different language roots). In Indonesia, English has been used quite widely in various kinds of media and in many occasions.

In this study, the writer highlighted how the students held their beliefs in learning other foreign languages in high school, those were Arabic and Japanese languages in SMAN 1 (public high school) in Pangkalpinang due to the fact that the students mostly had not learned both languages before they enrolled the schools. Furthermore, this is the only school which has one quite unfamiliar foreign language as the subject (Japanese). As the freshmen, their beliefs in learning those languages were interesting to be found out. In addition, they would like to learn the language on their own willing, as they had to choose between the two.

Preconception is closely related to 'belief'. An Indonesian learner might think that learning Japanese is more difficult than learning English since Japanese presents totally different kind of alphabets than the ones used in Bahasa, not to mention the pronunciations and vocabulary. Another case is a foreign language learner thinks he/she cannot be successful in learning another foreign language since he/she did not achieve well in learning the previous language.

Beliefs are a central construct in every discipline which deals with human behavior and learning. Learners' beliefs are obviously relevant with learning outcome. The beliefs the learners have will give effect on the way they learn a language. Teachers' beliefs influence their consciousness, teaching attitude, teaching methods 
and policies. Teachers' beliefs also strongly influence teaching behavior and learners' development. In other words, learners' beliefs and teachers' beliefs both have roles in the backwash of learning outcome, which can be positive or negative.

Beliefs about language learning are surely different for each learner in learning a foreign language. It will be a serious problem when the learners have the negative ones. Studies suggest that there is a correlation between the success of language learning and the beliefs the learner has about language learning. A successful language learner always has positive preconception of her/his learning and achievement. This is one thing the researcher would like to focus on in this research, to see how foreign language learners' beliefs about language learning in Indonesia, especially in Bangka Belitung.

Studies related to beliefs about language learning have been conducted by many researchers. One of them was by Johari et al. (2017) in Malaysia focusing on language beliefs among English adult learners. It suggested that they had various level of language beliefs. Another study was by Zareee (2010) in Iran. His study was focused on university students' beliefs and their learning strategy use. The result demonstrated that beliefs about language learning were significantly related to language learning strategy use and language proficiency. Language learners' self-efficacy about language learning and the perceived value of language learning were correlated with the use of all types of language learning strategies except metacognitive ones.

A study by Altan (2006) in Turkey with the sample of foreign language major university students suggested that the students held a range of beliefs with varying degrees of validity. Some results reported may surprise language teaching educators and teacher trainers, others probably confirm their experiences and intuitions. Ariogul et al. (2009) in their study which presented three groups of foreign language learners (English, German, and French), indicated that despite the more positive expectations of the French language learners compared to the others, all three groups held certain beliefs that would be detrimental to their long-term language learning.

In Hungary, Rieger (2009) investigated language learning beliefs of the first-year language major students studying English and German. The result showed a number 
Ihda Husnayaini

of significant differences of each aspect of beliefs based on gender and target language of the learners. Another study by Abdolahzadeh and Nia (2014) suggested that Iranian EFL learners reported strong beliefs in the categories of 'motivation and expectation' and 'foreign language aptitude', and there was a positive correlation between language proficiency and beliefs about language learning.

\section{B. The Dynamics of Language Learning and student Beliefs \\ 1. Language learning}

Language learning is conducted along with language acquisition or more popular with the term second language acquisition since the two is inseparable because learning a language can be done anywhere, not necessarily in the classroom context, and learning a language refers to a language after the learner's first language or mother tongue. Thus, second language acquisition can be defined as 'the way in which people learn a language other than their mother tongue, inside or outside of a classroom' (Ellis, 2003).

\section{Language Learning Beliefs}

Belief is an acceptance that something exists or is true, especially one without proof. It also means 'something one accepts as true or real; a firmly held opinion' (Oxford Living Dictionaries, 2018). According to Richardson (1996), beliefs are thought of as psychologically-held understandings, premises or propositions about the world that are felt to be true. Since they do not require a truth condition, it does not follow that everything a teacher believes or is willing to act on merits the label 'knowledge' (Naiman-Nemser \& Floden, 1986).

Champagne in Horwitz (1988) found that fifty Canadian students of French had low self-confidence in achieving good accent in French before they started the subject. It appeared that at the end of the semester, they failed to have a good French phonetic accuracy. This negative result could be worsened by the fact that the students' instructors shared the same hopelessness. This finding was quite consistent with a common belief that American adults are not able to speak a second or foreign language without their mother tongue accent. 
There have been many instances of studies presenting that preconceived idea about language learning influence the effectiveness of students' learning in the classroom. A student who believes that learning a foreign language requires a good mastery of vocabulary will learn how to master a lot of vocabulary of the language in question. He will try his best to achieve that. While some adult learners perceive that they are no better even lower learners than the younger ones and this can lead to low expectation of their success in language learning. Another case is some learners who are unsuccessful in their previous learning achievement will have negative perception toward their learning achievement that they actually need special competences which they think they do not even have.

Student beliefs about language learning would seem to have obvious relevance to the understanding of student expectations of, commitment to, success in, and satisfaction with their language classes. Studies of learner errors and interlanguage systems attempt to document learner hypotheses about the target language system but disregard more encompassing conceptions of the language learning task. On the other hand, several authors have discussed this topic. Holec (1987) argues that language learners must go through a sort of psychological preparation or 'deconditioning' to get rid themselves of preconceived notions and prejudices which would likely interfere with their language learning. Furthermore, Holec points out that the notion of learning itself can often be ambiguous to learners and offers several typical learner comments as examples of individual conceptions of the nature of learning: 1) learning a language is hard work; 2) for a Frenchman, learning Italian is easier than learning Japanese; 3) spelling is one of the major difficulties when learning French" (p. 145). Finally, Wenden examines learner theories about many aspects of language learning and explores the connection between these theories and students' self-reports of language learning strategies. In a series of interviews with ESL students, she finds that students described language learning strategies consistent with their professed beliefs about language learning.

\section{Language Learning Inventory: Beliefs}


The Beliefs about Language Learning Inventory (BALLI) was developed to assess student opinions on a variety of issues and controversies related to language learning. The BALLI contains thirty-four items and assesses student beliefs in five major areas: 1) difficulty of language learning; 2) foreign language aptitude; 3) the nature of language learning; 4) learning and communication strategies; and 5) motivations and expectations. Subjects are asked to read each item and then to indicate a response ranging from strongly agree to strongly disagree. A single composite score is not derived from the BALLI; rather, individual items yield descriptions of discrete student conceptions of language learning.

The first aspect, the Difficulty of Language Learning, concern the general difficulty of learning a foreign language and the specific difficulty of the student's particular target language. Foreign Language Aptitude concern the general existence of specialized abilities for language learning and beliefs about the characteristics of successful and unsuccessful language learners. This aspect includes the items addressing the issue of individual potential for achievement in language learning. The third aspect, the Nature of Language Learning, includes a broad range of issues related to the nature of the language learning process. The other aspect, Learning and Communication Strategies addresses learning and communication strategies and are probably the most directly related to a student's actual language learning practices. The last aspect, Motivation and Expectations, concerns desires and opportunities the students associate with the learning of their target language.

The BALLI was developed in several stages; items resulted from free-recall protocols of foreign language and ESL teachers of different cultural backgrounds, student (both foreign language and ESL) focus groups, and additional beliefs supplied by teacher educators from a variety of culture groups. In each case, subjects were asked to identify: 1) their own beliefs about language learning; 2) other people's beliefs about language learning; and, for teachers, 3 ) their current or former students' beliefs about language learning. The original version of this inventory consists of two: one in standard English for use with American foreign language students, and the other in simplified language for use with ESL students. An additional inventory has also been 
developed for use with foreign language teachers. In this study, the researcher just focused on the first one (for foreign language students).

The BALLI questions do not necessarily have clear-cut right and wrong answers. For example, one BALLI item concerns the common belief that children are better language learners than adults. Whether child superiority is a 'correct' or factual belief is not concern; rather, this inventory addresses the extent of such a belief among students and its consequences for language learning and teaching. Thus, Horwitz did not attempt to classify student opinions as correct or incorrect. Instead, she seek to describe specific beliefs and to discuss the potential impact of these beliefs on learner expectations and strategies.

\section{Method of Research}

The research the writer conducted is quantitative in the form of survey research, where investigators ask questions about peoples' beliefs, opinions, characteristics, and behavior. Quantitative research is a kind of research which uses objective measurement to gather numeric data that are used to answer questions or test predetermined hypotheses (Ary, Jacobs, \& Sorensen, 2010). While survey research is a type of research where investigators ask questions about peoples' belief, opinions, characteristics, and behavior. In other words, one of the characteristics of a survey research is: information is collected from a group of people in order to describe some aspects or characteristics (such as abilities, opinions, attitudes, beliefs, and/or knowledge) of the population of which that group is a part. The survey questionnaire is widely used as a source of data in studies in sociology, business, psychology, political science, and education (Ary, 2010).

In this study, the writer will conduct the administration of questionnaire distribution to the target sample (collecting data). The aim is to obtain information needed from the sample for further analysis. The information is the description of language learning beliefs of students of SMA Negeri 1 Pangkalpinang, Bangka Belitung in percentages and averages for each type of responses and groups. The response obtained was processed through data reduction, data display, and conclusion 
Ihda Husnayaini

drawing/verification. Data sources was obtained primarily from the questionnaire and interview.

\section{Population and Sample}

Population refers to the entire group of individuals to whom the findings of a study apply. This study will take the first grade of high school students of SMAN 1 Pangkalpinang who are going to learn Japanese and Arabic as the population.

Table 1. Population

\begin{tabular}{ccccc}
\hline No. & Clas₹ & Female & Male & All \\
\hline 1 & X MIA 1 & 16 & 18 & 34 \\
2 & X MIA 2 & 19 & 16 & 35 \\
3 & X MIA 3 & 18 & 15 & 33 \\
4 & X MIA 4 & 18 & 18 & 36 \\
5 & X MIA 5 & 19 & 17 & 36 \\
6 & X IPS 1 & 20 & 16 & 36 \\
7 & X IPS 2 & 19 & 17 & 36 \\
8 & X IPS 3 & 21 & 15 & 36 \\
9 & X IPS 4 & 13 & 17 & 30 \\
10 & Language & 19 & 14 & 33 \\
\hline \multicolumn{7}{c}{ All } & 182 & 163 & 345
\end{tabular}

\section{Sample}

Sample is the small group that is observed. It is a portion of a population. Sampling means a process of selecting a number of individuals (a sample) from a population, preferably in such a way that the individuals are representative of the larger group from which they were selected (Ary, Jacobs, \& Sorensen, 2010).

There are many types of sampling, one of them is census sampling, which was used in this research. Census sampling is a technique of sampling when all the population is used as a sample (Riduwan, 2012). In this survey research, actually the researcher did not use a sample due to the fact that she conducted a survey that covers the entire population of interest, which is called census, although according to Riduwan, it is a type of sampling.

This research used students of Among 345 students of the population, the writer eventually was able to use only 319 of them since the rest could not make it to attend the class on that day. Survey research is classified into two types on the basis of their scope (census versus sample) and their focus (tangibles and intangibles) (Ary, Jacobs, 
\& Sorensen, 2010). This research is categorized as a census of intangibles, where the researcher attempted to find a psychological aspect or construct of the subject of research (Ary, Jacobs, \& Sorensen, 2010).

\section{Technique for Collecting Data}

The data will be collected by distributing questionnaire sheets to the sample. After collecting the data, they will be analyzed by making average of the total score and percentages for each group of sample and items.

a. Validity

According to Ary, validity refers to the scope or degree of a test score on which a researcher can make appropriate and meaningful interpretations (Ary, 2010). When a researcher decided to use one instrument, he/she has to make sure the validity process has been done on selecting the instrument (Fraenkel, Wallen, Hyun, 2012).

After calculating the responses of the inventory, the researcher found that there were two statements not valid. Therefore the researcher was able to use the rest, which were 30 items.

b. Reliability

Reliability is defined as the consistency of an individual's score in terms of when the test is administered and what kinds of test items used (Fraenkel, Wallen, Hyun, 2012). In this study, it was found that the co-efficient of the inventory was 0.608 for 32 items. The next step implemented after obtaining the validity and reliability of the instrument was distributing the inventory to the sample.

\section{Technique for Analyzing Data}

The writer presents how the data will be analyzed by classifying the items of responses in the questionnaire and make the average points and percentages based on the result of responses and divides it into some categories, i.e. language class and gender. 
a. Classification of Language Learning Beliefs

In analyzing the inventory of language learning beliefs, the writer will use a categorization of language learning beliefs in terms of quality and descriptions.

Table 2. Score Range and Category of Agreement

\begin{tabular}{llc}
\hline \multicolumn{1}{c}{ Quality } & \multicolumn{1}{c}{ Descriptions } & Average Points \\
\hline \multirow{2}{*}{ High } & Strongly Agree & 4.5 to 5.0 \\
\multirow{2}{*}{ Medium } & Agree & 3.5 to 4.4 \\
\multirow{2}{*}{ Low } & Undecided & 2.5 to 3.4 \\
& Disagree & 1.5 to 2.4 \\
The categorization & Strongly Disagree & 1.0 to 1.4 \\
\hline
\end{tabular}

descriptions and average points for the Likert scale of five, with the lowest 1 and the highest 5 .

\section{Results and Discussion}

\section{The Prevalence of Language Learning Beliefs}

Here are the average result of Language Learning Beliefs of the high school students based on each class and gender.

Table 3. Average result

\begin{tabular}{|c|c|c|c|}
\hline No. & Class & Female Average & Male \\
\hline 1 & Arabic & 3.70 & 3.58 \\
\hline 2 & Japanese & 3.68 & 3.61 \\
\hline 3 & Mixed (Language Class) & 3.92 & 3.83 \\
\hline & All & 3.77 & 3.67 \\
\hline
\end{tabular}

The table shows that among the three classes of language group, mixed language class had the highest average number of language learning beliefs with 3.92 for female students and 3.83 for the males. Generally, female students also have a higher average number of language learning beliefs than the males with 3.77 , although both have almost the same number of average, nearly 4 . This suggested that the prevalence of each aspect are quite high. 


\section{The Responses of Language Learning Beliefs}

This part will discuss the average number of each response of the language learning beliefs of each class.

Table 4. Average based on class

\begin{tabular}{|c|c|c|c|c|}
\hline No & Aspects & - & $\begin{array}{l}\text { Average } \\
\text { Japanese }\end{array}$ & Mix \\
\hline 1 & Difficulty of Language Learning & 3.63 & 3.63 & 3.88 \\
\hline 2 & Foreign Language Aptitude & 3.38 & 3.38 & 3.74 \\
\hline 3 & The Nature of Language Learning & 3.66 & 3.65 & 4.00 \\
\hline 4 & $\begin{array}{l}\text { Learning and Communication } \\
\text { Strategies }\end{array}$ & 3.44 & 3.56 & 3.71 \\
\hline 5 & Motivations and Expectations & 3.88 & 3.88 & 4.25 \\
\hline & Total & 3.61 & 3.62 & 3.92 \\
\hline
\end{tabular}

The table above reveals that the language class (mix) has the highest average score for all aspects (3.92), followed by Japanese and Arabic classes with a very close range (3.62 and 3.61). In term of the aspect of belief, all of the three classes have the highest responses to motivations and expectations with the score 4.25 belonging to the mix language class. Overall, the average score for the whole aspects is 3.92 which is quite high.

\section{The Response of Each Aspect of Each Gender}

The table below describes the data of average number of each aspect based on gender.

Table 5. Average based on sex

\begin{tabular}{clll}
\hline \multirow{2}{*}{ No } & \multicolumn{2}{c}{ Aspects } & \multicolumn{2}{c}{ Female Average } & Male \\
\cline { 3 - 4 } & & 3.36 & 3.37 \\
\hline 1 & Difficulty of Language Learning & 3.52 & 3.39 \\
2 & Foreign Language Aptitude & 3.77 & 3.68 \\
3 & The Nature of Language Learning & 3.68 & 3.55 \\
4 & Learning and Communication Strategies & 4.28 & 4.08 \\
5 & Motivations and Expectations & 3,72 & 3,61 \\
\hline
\end{tabular}

Concerning gender, the responses from both male and female students reflect quite a similar level of averages, which is classified as high, with the highest number of average in Motivations and Expectations (4.08 and 4.28). In other words, there was not much difference of what the male and female students desired and hoped about what they wanted to achieve in language learning. Both had positive responses to all 
of the aspects, especially the one related to desires and expectations. In general, the female students had slightly higher score than the males (3.72 as opposed to 3.61). This suggested that, overall, most of the students had high motivations and expectations to learn a foreign language both Japanese and Arabic, in this case.

\section{The Prevalence of Beliefs of All Language Classes}

The tables below will explain the results in the form of mean and percentages of frequencies for each item of students' language learning beliefs.

Table 6. The Difficulty of Language Learning

\begin{tabular}{|c|c|c|c|c|}
\hline No. & Items & Mean & $\begin{array}{c}\text { Std. } \\
\text { Deviation }\end{array}$ & $\begin{array}{l}\text { Highest } \\
\text { Frequencies }\end{array}$ \\
\hline 1 & Some languages are easier to learn than others. & 3.88 & .730 & A $65 \%$ \\
\hline 2 & $\begin{array}{l}\text { I believe that I will ultimately learn to speak this } \\
\text { language very well. }\end{array}$ & 4.10 & .696 & A $54 \%$ \\
\hline 3 & $\begin{array}{l}\text { It is easier to read and write this language than to } \\
\text { speak and understand it. }\end{array}$ & 3.40 & 1.026 & A $32 \%$ \\
\hline 4 & $\begin{array}{l}\text { It is easier to speak than understand a foreign } \\
\text { language. }\end{array}$ & 3.14 & .938 & $\mathrm{U} 38 \%$ \\
\hline
\end{tabular}

*SA-Strongly agree; A-Agree; U-Undecided; D-Disagree; SD-Strongly Disagree

The difficulty of language learning concerns the different level of difficulties of learning a foreign language. Most of students, in general, perceived that some languages are easier to learn than others, with the highest average number of percentage (65\% who agreed). Furthermore, they were quite confident that they could certainly learn to speak in the language ( $54 \%$ who agreed). The other items which the students also agreed mostly are the third where they believed that they could learn to read and write using the foreign language they chose even better than they had to speak and understand their respective languages. However, they could not decide to agree nor disagree that speaking is easier than understanding the foreign language.

Table 7. Foreign Language Aptitude

\begin{tabular}{clccc}
\hline No. & \multicolumn{1}{c}{ Items } & Mean & $\begin{array}{c}\text { Std. } \\
\text { Deviation }\end{array}$ & $\begin{array}{c}\text { Highest } \\
\text { Frequencies }\end{array}$ \\
\hline 5 & $\begin{array}{l}\text { It is easier for children than adults to learn a } \\
\text { foreign language }\end{array}$ & 4.02 & .746 & A 59\% \\
$6 \begin{array}{l}\text { Women are better than men at learning foreign } \\
\text { languages. }\end{array}$ & 2.68 & 1.077 & D 36\% \\
7 & $\begin{array}{l}\text { Some people are born with a special ability } \\
\text { which helps them learn a foreign language. }\end{array}$ & 3.51 & 1.009 & A 48\%
\end{tabular}




\begin{tabular}{|c|c|c|c|c|}
\hline No. & Items & Mean & $\begin{array}{c}\text { Std. } \\
\text { Deviation }\end{array}$ & $\begin{array}{l}\text { Highest } \\
\text { Frequencies }\end{array}$ \\
\hline 8 & $\begin{array}{l}\text { It is easier for someone who already speaks a } \\
\text { foreign language to learn another one. }\end{array}$ & 3.61 & .855 & A $49 \%$ \\
\hline 9 & $\begin{array}{l}\text { People who are good at maths and science are } \\
\text { not good at learning foreign languages. }\end{array}$ & 2.19 & .937 & D $47 \%$ \\
\hline 10 & I have foreign language aptitude. & 3.54 & .807 & A $45 \%$ \\
\hline 11 & $\begin{array}{l}\text { Indonesians are good at learning foreign } \\
\text { languages. }\end{array}$ & 3.49 & .764 & $\mathrm{U} 46 \%$ \\
\hline 12 & $\begin{array}{l}\text { People who speak more than one language well } \\
\text { are very intelligent. }\end{array}$ & 3.75 & 1.001 & A $42 \%$ \\
\hline 13 & Everyone can learn to speak a foreign language. & 4.36 & 699 & SA $46 \%$ \\
\hline
\end{tabular}

Table above reveals how the students responded their foreign language

aptitude. Most of them advocated the concept of special abilities for language learning. They agreed with most of the statements which one of them is that some people have a special ability in learning a foreign language since they were born (48\%). They also thought that it is easier for an individual who already learns a foreign language to learn a new one (49\%). Furthermore, they were with the idea that people who are good in more than one language, especially in speaking, are very smart (42\%). They also believed that they had a natural ability to learn a foreign language. Additionally, more than half of the students (59\%) thought that learning a foreign language was easier for children than adults. Moreover, there were $46 \%$ of the students strongly agreed with the assertion that every individual can learn to speak any foreign language.

Despite the fact that average students agreed with the majority of the statements of foreign language aptitude, they did not agree that gender has a role in producing better learners in language learning, in this case, females have better foreign language aptitude than males (around 36\% disagreed). The same response went to another study suggesting that people who are well achievers of science are not good in foreign language learning (47\% disagreed). Meanwhile, there were about $46 \%$ could not decide whether to agree nor disagree that Indonesians in general are good foreign language learners. 
Table 8. The Nature of Language Learning

\begin{tabular}{clccc}
\hline No. & \multicolumn{1}{c}{ Items } & Mean & $\begin{array}{c}\text { Std. } \\
\text { Deviation }\end{array}$ & $\begin{array}{c}\text { Highest } \\
\text { Frequencies }\end{array}$ \\
\hline 14 & $\begin{array}{l}\text { Learning a foreign language is mostly a matter of } \\
\text { translating from Bahasa into Arabic/Japan. }\end{array}$ & 3.91 & .838 & A 55\% \\
15 & $\begin{array}{l}\text { Learning a foreign language is mostly a matter of } \\
\text { learning a lot of new vocabulary words. }\end{array}$ & 4.23 & .659 & A 56\% \\
$16 \quad \begin{array}{l}\text { Learning a foreign language is mostly a matter of } \\
\text { learning a lot of grammar rules. }\end{array}$ & 3.68 & .775 & A 57\% \\
$17 \quad \begin{array}{l}\text { It is necessary to know the foreign culture in order } \\
\text { to speak the foreign language. }\end{array}$ & 3.70 & .846 & A 50\% \\
18 & $\begin{array}{l}\text { Learning a foreign language is different from } \\
\text { learning other school subjects. }\end{array}$ & 3.63 & .786 & A 53\% \\
19 & $\begin{array}{l}\text { It is better to learn the foreign language in the } \\
\text { foreign country. }\end{array}$ & 3.21 & 1.002 & U 33\% \\
\hline
\end{tabular}

*SA-Strongly agree; A-Agree; U-Undecided; D-Disagree; SD-Strongly Disagree

This aspect is related to issues in language learning process. In most of the statements, above half of the students affirmed with $50 \%$ minimum, concerning the need to be informed of the culture of the language they learn as well as the need to learn one language in the country of the native speakers in spite of there were about $33 \%$ undecided regarding the latter. The students apparently realized that language is a part of culture that it is important to learn the language and the culture at the same time.

A quite high percentage of the students (above 50\%) agreed that learning a foreign language is about learning its grammatical rules (57\%), as well as the vocabulary $(56 \%)$. The students also believed that learning a language takes a special skill compared to other subjects (53\%) and involves the skill of translating from L1, in this case Bahasa, to the target language (55\%).

Table 9. Learning and Communication Strategies

\begin{tabular}{|c|c|c|c|c|}
\hline No. & Items & Mean & $\begin{array}{c}\text { Std. } \\
\text { Deviation }\end{array}$ & $\begin{array}{l}\text { Highest } \\
\text { Frequencies }\end{array}$ \\
\hline 20 & It is important to repeat and practice a lot. & 4.53 & .628 & SA $59 \%$ \\
\hline 21 & $\begin{array}{l}\text { It's okay to guess if you don't know a word in a } \\
\text { foreign language. }\end{array}$ & 3.76 & .785 & A $55 \%$ \\
\hline 22 & $\begin{array}{l}\text { It is important to speak a foreign language with } \\
\text { an excellent accent. }\end{array}$ & 3.90 & .908 & A $51 \%$ \\
\hline 23 & $\begin{array}{l}\text { You shouldn't say anything in a foreign language } \\
\text { until you can say it correctly. }\end{array}$ & 2.51 & 1.049 & D $46 \%$ \\
\hline
\end{tabular}




\begin{tabular}{clccc}
\hline No. & \multicolumn{1}{c}{ Items } & Mean & $\begin{array}{c}\text { Std. } \\
\text { Deviation }\end{array}$ & $\begin{array}{c}\text { Highest } \\
\text { Frequencies }\end{array}$ \\
\hline 24 & $\begin{array}{l}\text { If I heard someone speaking in the language I } \\
\text { am trying to learn, I would go up to them so that }\end{array}$ & 3.90 & .752 & A 54\% \\
$\begin{array}{l}\text { I could practice speaking the language. } \\
\text { I feel self-conscious speaking the foreign } \\
\text { language in front of other people. }\end{array}$ & 3.75 & .726 & A 58\% \\
26 & $\begin{array}{l}\text { If you are allowed to make mistakes in the } \\
\text { beginning it will be hard to get rid of them later } \\
\text { on. }\end{array}$ & 3.00 & 1.093 & D 30\%
\end{tabular}

*SA-Strongly agree; A-Agree; U-Undecided; D-Disagree; SD-Strongly Disagree

This aspect consists of two kinds of strategies: learning strategies (item no. 20) and communication strategies. The result above reveals that the students mostly agreed with most of the statements, except item no. 23 and 26, around 46\% and 30\% disagreed. They really believed that repeating and practicing by speaking and writing frequently is very essential in learning a language (59\%). Concerning the communication strategies, they accepted that guessing strategy can be used in communication (55\%). In addition, for the students, social strategy is also important to improve a learner's language ability, in this case, having a conversation with a native speaker of the language they are learning or anyone who is learning the language (54\%). This strategy also applies when practicing speaking in front of public in any opportunity. The students mostly felt confidence in doing this, meaning they did not hesitate to speak in public (58\%).

There are some tolerable mistakes in language learning activities (23 \& 26) because, according to them, making mistakes is a part of learning, therefore a learner can practice the language they are learning either by speaking or writing without getting afraid of making mistakes. In other words, a learner just needs to try to practice the language they are learning without being concerned too much for mistakes they might make, especially in terms of pronunciation and accuracy. That is why some of them disagreed with the item 23 and 26 (46\% and 30\%).

Table 10. Motivations and Expectations

\begin{tabular}{clccc}
\hline No. & \multicolumn{1}{c}{ Items } & Mean & $\begin{array}{c}\text { Std. } \\
\text { Deviation }\end{array}$ & $\begin{array}{c}\text { Highest } \\
\text { Frequencies }\end{array}$ \\
\hline 27 & $\begin{array}{l}\text { If I get to speak this language very well, I will } \\
\text { have many opportunities to use it. }\end{array}$ & 4.38 & .612 & A 48\% \\
28 & $\begin{array}{l}\text { I would like to learn this language so that I can } \\
\text { get to know its speakers better. }\end{array}$ & 3.92 & .733 & A 63\%
\end{tabular}




\begin{tabular}{|c|c|c|c|c|}
\hline 29 & $\begin{array}{l}\text { If I learn to speak this language very well, it will } \\
\text { help me get a good job. }\end{array}$ & 4.26 & .814 & SA $45 \%$ \\
\hline 30 & $\begin{array}{l}\text { Indonesians think that it is important to speak } \\
\text { a foreign language. }\end{array}$ & 4.07 & .806 & A $51 \%$ \\
\hline
\end{tabular}

*SA-Strongly agree; A-Agree; U-Undecided; D-Disagree; SD-Strongly Disagree

The data above reveals positive responses (Agree and Strongly Agree) to the items regarding the students' desire and the opportunities they can have with the highest response of acceptance (Strongly Agree) toward the statement concerning the opportunity of getting the job they expect by learning how to speak the language the best way they can (45\%). Moreover, they believed that they will have a lot of opportunities to practice speaking the target language if they are able to speak the language well (48\%). The response of the item no. 28 reflects that they are interested in learning the language in order to get to know more about the speakers, so they can speak better with them well as they expect. In other words, they are motivated to learn the target language because they want to learn how the speakers speak as they believed that the best way to learn speaking is by imitating how the native speakers speak since that is the most original way.

Another positive response they had is regarding their opinion about Indonesian people. According to them, in general, Indonesians are types of people who think that being able to speak a foreign language is one skill they should have.

\section{The Responses of Language Learning Beliefs}

As revealed in the finding, the students of all classes had the average score of all the aspects categorized high or positive responses. Many factors may have roles in achieving this. The school itself has been many middles school graduates' favorites. Therefore, only the best who enrolled the school. This year, the school have two foreign languages as the optional subjects, Arabic and Japanese. The other class is language class where it provides the two foreign languages to learn, unlike the former classes, it is learned as compulsory subjects. Therefore, most of the students, as good achievers, had relatively high scores in all aspects, especially in motivations and expectations. However, the language class (mix) had the highest one. As the language students, certainly they focused on learning languages, especially foreign languages 
(Arabic and Japanese) more than the students of the other classes. Moreover, those from the other classes do not focus on learning the language since they are from science and social science classes.

\section{The Response of Each Aspect of Each Gender}

As has been revealed by many studies that gender has a role in language learning, this study also disclosed that there was a difference of the result between female and male students, although they are not much different. Females, in general, are better language learners than men, as a study in Northwestern University in 2008 revealed.

Having better innate verbal skills, the female students outscored the males in all aspects of the beliefs, especially in motivation and expectations. This can be linked to the fact that females' brains display more active in the areas of language encryption than males'. In other words, women are better in all language skills in general than men. Those facts are unquestionably related to the beliefs of language learning they had.

The first thing revealed from this study is that most of the students of this high school had positive responses to language learning beliefs statements. This can be related to the background of the individuals that they are good learners, therefore they had positive opinions about all aspects of the beliefs, especially in motivations and expectations.

The second one, regarding gender, this study suggested that when it comes to language learning, females, in general, are better learners than males. They had more positive judgment of language learning beliefs, especially in motivating themselves in learning a foreign language and taking opportunities to learn the language. The result matches many previous studies revealing that women are better in language learning than men, including language learning beliefs.

\section{E. Suggestions}

This study discusses language learning beliefs of high school students who learn foreign languages, Japanese and Arabic as their school subjects with the analysis 
Ihda Husnayaini

of differences based on gender. There is much more enabled to discuss for further studies regarding variables of study, the samples and the analysis.

For the teacher or lecturer of foreign language subjects, having students who have positive beliefs of language learning, and usually good learners as well, may enable the teacher or lecturer to teach better and with more confidence. However, when they have to teach those with negative opinions of language learning, and lower achievers, this can be more challenging. Above all, a good teacher should always be well-prepared before entering the classroom, not only about the learning material, but also the learning method to use, regardless the class situation. 


\section{References}

Abdolahzadeh, E. \& Nia, M. R. (2014). Language learning beliefs of Iranian Learners: Examining the Role of English Language Proficiency. Procedia Social and Behavioral Sciences. Vol. 98.

Altan, M. Z. 2006. Beliefs about Language Learning of Foreign Language-Major University Students. Australia Journal of Teacher Education. Vol. 31, No. 2.

Ariogul, S., Unal, D. C., \& Onursal, I. 2009. Foreign Language Learners’ Beliefs about Language Learning: A Study on Turkish University Students. Procedia Social and Behavioral Sciences. Vol. 1.

Ary, D., Jacobs, L. C., \& Sorensen, C. 2010. Introduction to Research in Education. Belmont, CA: Wadsworth.

Brown, H. D. 2002. Principles of Language Learning and Teaching. New York: Pearson Education.

Champagne, C. M. 1980. La Composante Phonetique dans les Cours de Francais Langue Seconde. MA Thesis. In Horwitz, E. K. 1988. The Beliefs about Language Learning of Beginning University Foreign Language Students. The Modern Language Journal, Vol. III No. 72.

Ellis, R. 2003. Introduction to Language Study: Second Language Acquisition. Oxford: Oxford University Press.

Holec, H. 1987. The Learner as Manager: Managing Learning of Managing to Learn? Learner Strategies in Language Learning. Ed. Anita Wenden \& Joan Rubin. Englewood Cliffs, NJ: Prentice -Hall.

Horwitz, E. K. 1988. The Beliefs about Language Learning of Beginning University Foreign Language Students. The Modern Language Journal, Vol. III No. 72.

Johari, A. et al. 2017. Language Beliefs among Adult Learners: Individual Differences. International Journal of Education. Vol. 10, No. 1.

Naiman, N., Frohlich, M., Stern, H. \& Todesco, A. 1978. The Good Language Learner. Toronto: Ontario Institute for Studies in Education. In Holec, H. 1987. The Learner as Manager: Managing Learning of Managing to Learn? Learner Strategies in Language Learning. Ed. Anita Wenden \& Joan Rubin. Englewood Cliffs, NJ: Prentice -Hall.

Oxford, R. 1990. Language Learning Strategies: What Every Teacher Should Know. Boston: Heinle \& Heinle Publishers.

Richardson, V. 1996. The Role of Attitudes and Beliefs in Learning to Teach. Research Gate. In Sikula, J. (Ed.). 1996. Handbook of Research on Teacher Education (2nd Edition). New York: MacMillan.

Rieger, B. 2009. Hungarian University Students’ Beliefs about Language Learning: A Questionnaire Study. WoPaLP. Vol. 3.

Zare-ee, A. 2010. Associations between University Students' Beliefs and Their Learning Strategy Use. Procedia Social and Behavioral Sciences. Vol. 5. 